\title{
EVALUATION OF GROWTH IN PIKE (Esox lucius L., 1758) USING TRADITIONAL METHODS AND ARTIFICIAL NEURAL NETWORKS
}

\author{
BENZER, S. $^{{ }^{*}}-$ BENZER, $^{2}{ }^{2}$ \\ ${ }^{1}$ Gazi University, Gazi Faculty of Education \\ Teknikokullar, 06500 Ankara, Turkey \\ ${ }^{2}$ Gazi University, Institute of Information \\ Teknikokullar, 06500 Ankara, Turkey \\ *Corresponding author \\ e-mail: sbenzer@gazi.edu.tr \\ (phone: +90-505-6603181; fax: +90-312-202-1608) \\ (Received 22 ${ }^{\text {nd }}$ Apr 2015; accepted 24 $4^{\text {th }}$ Mar 2016)
}

\begin{abstract}
The present study was performed to assess the population structure and growth of pike in Mogan Lake using length-weight relationships, von Bertalanffy equations and artificial neural networks between February 2013 and March 2014. The age of Esox lucius caught in Mogan Lake ranged between I to VII years. The fork length of the fish ranged from $27.5 \mathrm{~cm}$ to $70.0 \mathrm{~cm}$, and the body weight of the fish ranged from $200 \mathrm{~g}$ to $2820 \mathrm{~g}$. The von Bertalanffy growth lengths were 130.30 for females, 122.70 for males and 126.50 for all individuals. The von Bertalanffy growth weights were 18889 for females, 14881 for males and 16688 for all pike. The results obtained using the artificial neural networks and regression technique were compared to those obtained using the growth rate of the fish caught from the natural environment and von Bertalanffy growth model. Artificial neural networks are an alternative to von Bertalanffy growth models.
\end{abstract}

Keywords: growth, artificial neural networks, Esox lucius, von Bertalanffy, Mogan Lake

\section{Introduction}

Pike (Esox lucius L., 1758) is a widely distributed species of fish in Turkey and one of the most valuable fish in inland waters (Çubuk et al., 2005). It is an essential element of the ecosystem as a piscivore and can tolerate a wide range of environmental conditions (Casselman and Lewis, 1996). This species is of high economic importance in the fisheries of Mogan Lake. Despite its importance, few studies have been conducted on the pike population in Mogan Lake.

There is a large body of literature regarding the growth properties of pike in various water reservoirs. Tanyolaç and Karabatak (1974) examined its growth properties in Mogan Lake, Aksun (1987) in Karamık Lake, Karabatak (1993) Akşehir in Lake, Treer et al. (1998) in Croatian Reservoir, Altındağ et al. (1999) in Kesikköprü Dam Lake, Lorenzoni et al. (2002) in Trasimeno Lake, Küçük and Güçlü (2004) in Çapalı Lake, Çubuk et al. (2005) in Karamık Lake, Gaygusuz et al. (2006) in Terkos Dam Lake, Erdem et al. (2007) in Uluabat Lake, Uysal et al. (2008) in Işıklı Lake, Yağc1 et al. (2009) in Işıklı Dam Lake, Ziliukiene and Ziliukas (2010) in Lake Rubikiai, and Moslemi-Aqdam et al. (2014) in Anzali Wetland.

Much research has been performed regarding the prediction of future data using artificial neural networks (ANNs) because they exhibit better results than traditional methods found in the literature (Hill et al., 1996; Hamzacebi and Kutay, 2004; 
Suryanarayana et al., 2008; Türeli Bilen et al. 2011; Christiansen et al., 2014; Benzer, 2014). These studies showed that neural network models are significantly better than traditional statistical and human judgment methods when forecasting monthly and quarterly data (Desilets et al., 1992).

The present study investigated the growth of Esox lucius and provides information regarding the population structure (age, growth and sex ratio) of pike in Mogan Lake between February 2013 and March 2014.

\section{Materials and methods}

\section{Study site}

Mogan Lake is located approximately $20 \mathrm{~km}$ south of Ankara, the capital of Turkey, and lies within the coordinates $39^{\circ} 44^{\prime} 40^{\prime \prime} \mathrm{N}$ and $39^{\circ} 47^{\prime} 45^{\prime \prime} \mathrm{N}$ latitudes and $32^{\circ} 46^{\prime} 30^{\prime \prime} \mathrm{E}$ and $32^{\circ} 49^{\prime} 30^{\prime \prime} \mathrm{E}$ longitudes (Figure 1). It is near Gölbaş1 town, which has become economically and socially developed and has had an increasing population and settlement in recent years. A large number of commercial establishments, such as restaurants, social clubs, and tea gardens, as well as summer resorts, have been built around the lake, which has become a popular site for sports, fishing, sailing, and rowing (Anonymous, 1989).

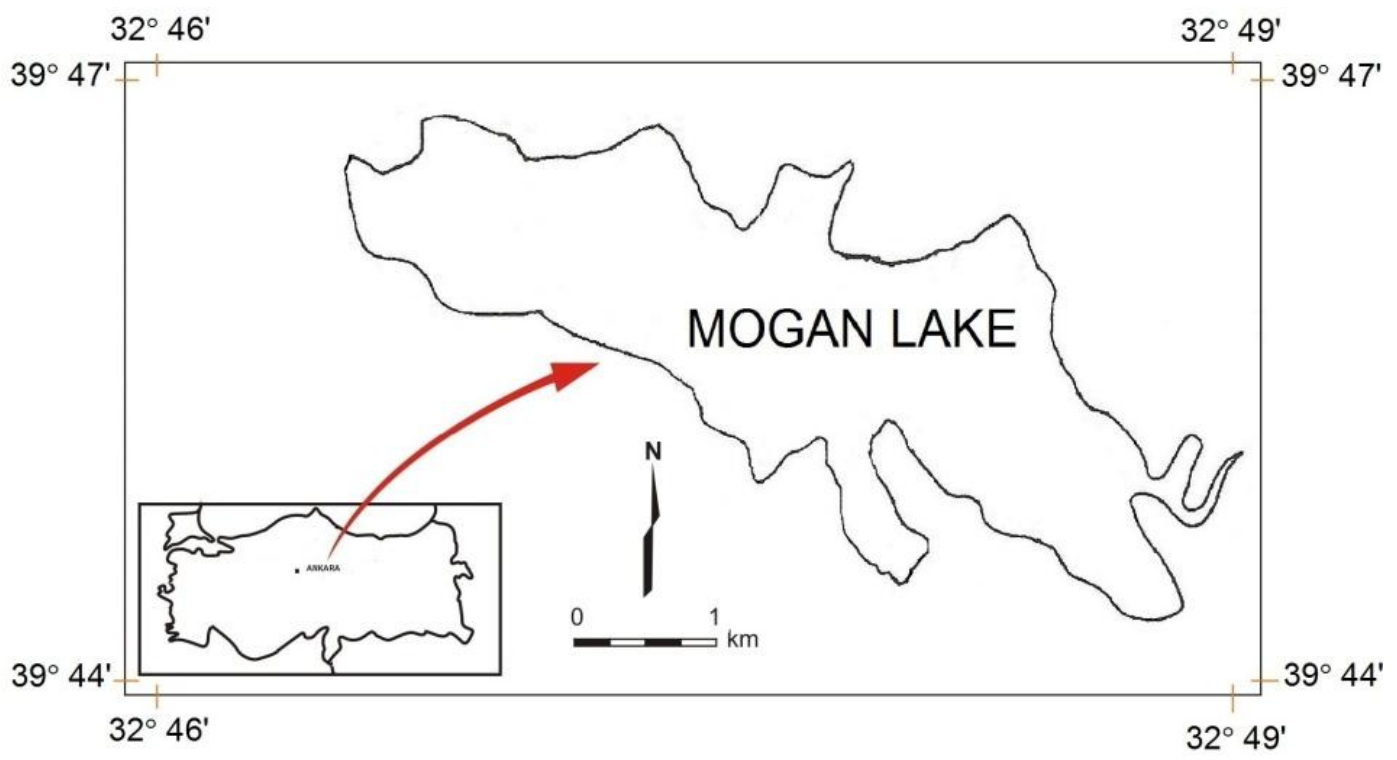

Figure 1. Map of Mogan Lake

\section{Sampling / Data Collection}

Fish samples (Esox lucius L., 1758) were collected from Mogan Lake. During the study, 431 fish specimens were caught between February 2013 and March 2014. The fish obtained from the lake were immediately transported to the laboratory. The length and weight (min-max) of the fish were $275-700 \mathrm{~mm}$ and $200-2820 \mathrm{~g}$, respectively. Scales were sampled from each specimen to identify their age according to the method of Lagler (1966). 


\section{Length-weight relations}

The length-weight relationships were estimated from the formula $\mathrm{W}=\mathrm{a} \mathrm{L}^{\mathrm{b}}$, where $\mathrm{W}$ is total body weight $(\mathrm{g}), \mathrm{L}$ is the total length $(\mathrm{mm})$, and $\mathrm{a}$ and $\mathrm{b}$ are the coefficients of the functional regression between W and L (Ricker, 1973). The equation was log transformed to estimate the parameters ' $a$ ' and ' $b$ '. When $b$ is equal to three (3), an isometric growth pattern occurs, but when $\mathrm{b}$ is not equal to 3 , an allometric growth pattern occurs, which is positive if $>3$ or negative if $<3$.

\section{Von Bertalanffy equations}

Growth was estimated using the von Bertalanffy growth curve model (Eq.1 and Eq.2) according to Sparre and Venema (1992).

$$
\begin{gathered}
L_{t}=L_{\infty}\left[1-e^{-K\left(t-t_{0}\right)}\right] \text { for length } \\
W_{t}=W_{\infty}\left[1-e^{-K\left(t-t_{0}\right)}\right]^{b} \text { for weight }
\end{gathered}
$$

where $\mathrm{L}_{\mathrm{t}}=$ the fork length $(\mathrm{cm})$ at age $\mathrm{t}, \mathrm{L}_{\infty}=$ the asymptotic length (theoretical maximum length), $\mathrm{k}=$ the Brody growth coefficient (proportional to the rate at which $\mathrm{L}_{\infty}$ is reached), $\mathrm{t}=$ the age (years), $\mathrm{t}_{0}=$ the age at zero length, $\mathrm{e}$ is the base of natural log (2.71828), $\mathrm{W}_{\mathrm{t}}$ is the weight of the fish in $\mathrm{g}$ at age $\mathrm{t}, \mathrm{W}_{\infty}$ is the asymptotic weight of (theoretical maximum weight) the fish in $g$ and $b$ is the constant in the length-weight relationship. The von Bertalanffy growth parameters were estimated for males and females independently, as well as for both sexes combined.

\section{Artificial Neural Networks}

The ANN provides a better model because it produces better predictions for lower values, and the normality of the residuals and their independence from the predicted variables are also improved. Several authors reported greater performances of ANNs compared to linear regressions (Sun et al., 2009). ANNs have another advantage in that the ANN modelling approach is fast and flexible (Brosse et al., 1999). In this study, the ANN is a new and alternative approach for predicting the growth and weight of pike compared to traditional methods.

ANNs are computational systems that simulate biological neural networks and can be defined as a specific type of parallel processing system based on distributional or connectionist methods (Hopgood, 2000). They appear to be more functional for predicting the future. ANNs can reveal the power relationships between unknown and unidentified data. By contrast, ANNs are simulations of biological nervous systems using mathematical models. They are networks with simple processor units, interconnections, adaptive weights and scalar measurement functions (e.g. summation and activation functions) (Rumelhart et al., 1986).

During the training of the network, the input data and input-output relationship between the learning of the network is provided. This method, generally called supervised learning, is a preferred method (Haykin, 1999). The supervised learning method trained with the network structure (back-propagation networks) was used to solve problems in this study. 
The sum squared error (SSE) and mean absolute percentage error (MAPE) were used in the study as the two performance criteria (Matlab, 2006). SSE was used as a criterion to determine training during the training of the network. In addition, comparisons were made involving more than one method because the MAPE of each provides information about the average relative size of their errors.

SSE and MAPE are described by equations Eq.3 and Eq.4, respectively.

$$
\begin{gathered}
S S E=\sum_{i=1}^{n} e_{i}^{2} \\
M A P E=\frac{1}{n} \sum_{i=1}^{n}\left|\frac{e_{i}}{Y_{i}}\right| * 100
\end{gathered}
$$

where $Y_{i}$ is the actual observation value, $e_{i}$ is the difference between the actual value and the prediction value, and $\mathrm{n}$ is the number of total observations.

\section{Data and identification models}

The Neural Network Toolbox of MATLAB was used for the ANN calculations. This study was performed using 431 Esox lucius (157 females, 235 males and 39 immature individuals) caught between February 2013 and March 2014 in Mogan Lake. The data were divided into three equal parts, training, validation, and test sets. The MATLAB functions were used for "training", "testing", and "validation". They were used randomly, with $70 \%$ for training, $15 \%$ for testing, and $15 \%$ for the validation of fish.

\section{Results}

There were $36.43 \%$ females, $54.52 \%$ males and $9.05 \%$ immature fish. The differences among different age groups were not statistically significant $(p>0.05)$. The age ranged between I to VII years.

The male:female ratio was 1.49:1 for the general population. The prevailing climatic conditions during the study were predicted to affect the sexual maturity, breeding, breeding time, egg development, and egg hatching (Hellawell, 1971).

Most of the samples studied in this study belonged to the III-year age group (Table 1). The females were longer and heavier than the males in the III, IV and VI-year age groups.

Table 1. Age structure, parameters of the length-weight relationship ( $a$ and $b)$, growth $\left(L_{\infty}\right.$,

\begin{tabular}{|c|c|c|c|c|c|c|c|c|c|c|c|c|}
\hline Authors & & & $\begin{array}{c}\text { Length } \\
\text { Min-max }\end{array}$ & $\begin{array}{c}\text { Age } \\
\text { Range }\end{array}$ & $\mathbf{a}$ & b & $\mathbf{r}^{2}$ & $\begin{array}{c}\mathbf{L}_{\infty} \\
(\mathbf{c m})\end{array}$ & $\begin{array}{l}\mathbf{W}_{\infty} \\
(\mathrm{g})\end{array}$ & $\underset{\left(\text { year }^{-1)}\right.}{\mathbf{K}}$ & $\begin{array}{c}\mathbf{t}_{0} \\
\text { (year) }\end{array}$ & $\mathbf{C F}$ \\
\hline $\begin{array}{c}\text { Karabatak } \\
\text { (1993) }\end{array}$ & $\begin{array}{l}\text { p } \\
+ \\
\text { o }\end{array}$ & $\mathrm{L}$ & $33.66-67.10$ & $1-7$ & $\begin{array}{l}2.71 \\
2.22\end{array}$ & $\begin{array}{l}3.38 \\
3.08\end{array}$ & - & $\begin{array}{l}136.46 \\
160.46\end{array}$ & $\begin{array}{l}320.88 \\
379.00\end{array}$ & $\begin{array}{l}0.062 \\
0.048\end{array}$ & $\begin{array}{l}-3.59 \\
-4.06\end{array}$ & $\begin{array}{l}0.83 \\
0.81\end{array}$ \\
\hline $\begin{array}{c}\text { Treer et al. } \\
\text { (1998) }\end{array}$ & q઼ & - & - & - & - & - & - & 142.0 & - & 0.140 & 0.500 & - \\
\hline $\begin{array}{l}\text { Altındağ et } \\
\text { al.(1999) }\end{array}$ & $\begin{array}{l}0 \\
+ \\
0 \\
0\end{array}$ & $\begin{array}{c}\mathrm{L} \\
\mathrm{cm}\end{array}$ & $25.2-53.4$ & $0-5$ & $\begin{array}{l}2.59 \\
2.21\end{array}$ & $\begin{array}{l}3.36 \\
3.10\end{array}$ & - & $\begin{array}{l}114.76 \\
145.49\end{array}$ & $\begin{array}{l}21942.81 \\
31915.62\end{array}$ & $\begin{array}{l}-0.075 \\
-0.056\end{array}$ & $\begin{array}{l}-3.349 \\
-3.318\end{array}$ & $\begin{array}{r}0.863- \\
1.005\end{array}$ \\
\hline
\end{tabular}
$\left.K, t_{0}\right)$ and $C F$ of Esox lucius. 


\begin{tabular}{|c|c|c|c|c|c|c|c|c|c|c|c|c|}
\hline $\begin{array}{l}\text { Lorenzoni et al. } \\
\qquad(2002)\end{array}$ & 위 & $\begin{array}{l}\mathrm{FL} \\
\mathrm{cm}\end{array}$ & - & - & - & 3.04 & 0.99 & 162.76 & - & 0.089 & 0.291 & - \\
\hline $\begin{array}{c}\text { Küçük And } \\
\text { Güçlü (2004) }\end{array}$ & q0َ & - & - & - & 0.226 & 2.719 & & 48.84 & - & 0.416 & 1.449 & 0.877 \\
\hline $\begin{array}{l}\text { Çubuk et al. } \\
\text { (2005) }\end{array}$ & $\begin{array}{l}0 \\
+\lambda \\
\hat{0} \\
+\hat{0}\end{array}$ & $\begin{array}{l}\mathrm{FL} \\
\mathrm{cm}\end{array}$ & $\begin{array}{c}22.50- \\
50.0\end{array}$ & $1-5$ & $\begin{array}{l}0.0060 \\
0.0063 \\
0.0059\end{array}$ & $\begin{array}{l}3.10 \\
3.07 \\
3.10\end{array}$ & - & $\begin{array}{l}117.0 \\
123.1 \\
121.6\end{array}$ & & $\begin{array}{l}0.089 \\
0.098 \\
0.092\end{array}$ & $\begin{array}{l}0.74 \\
0.74 \\
0.75\end{array}$ & - \\
\hline $\begin{array}{l}\text { Gaygusuz et al. } \\
\text { (2006) }\end{array}$ & +ô & $\begin{array}{l}\mathrm{SL} \\
\mathrm{cm}\end{array}$ & $28.9-54.1$ & - & 2.8931 & 1.0489 & - & - & - & - & - & - \\
\hline $\begin{array}{l}\text { Erdem et al. } \\
\quad(2007)\end{array}$ & +ổ & $\begin{array}{l}\mathrm{FL} \\
\mathrm{cm}\end{array}$ & $\begin{array}{c}30.11- \\
54.85\end{array}$ & $1-5$ & - & - & - & - & - & - & - & 0.90 \\
\hline $\begin{array}{l}\text { Uysal et al. } \\
\text { (2008) }\end{array}$ & $\begin{array}{l}\text { q } \\
\text { o } \\
0^{\lambda}\end{array}$ & $\begin{array}{l}\mathrm{FL} \\
\mathrm{cm}\end{array}$ & $23-49.4$ & $1-6$ & - & - & - & $\begin{array}{l}117.8 \\
118.0\end{array}$ & $\begin{array}{l}18003 \\
21983\end{array}$ & $\begin{array}{l}0.067 \\
0.067\end{array}$ & $\begin{array}{l}2.36 \\
1.97\end{array}$ & - \\
\hline $\begin{array}{l}\text { Ziliukiene and } \\
\text { Ziliukas (2010) }\end{array}$ & & - & $\begin{array}{c}26.50- \\
107.0\end{array}$ & $2-12$ & 0.06 & 3.02 & - & 131.7 & 14870 & 0.150 & 0.040 & - \\
\hline $\begin{array}{c}\text { Moslemi- } \\
\text { Aqdam et al. } \\
\text { (2014) }\end{array}$ & +ô & $\begin{array}{l}\mathrm{FL} \\
\mathrm{cm}\end{array}$ & $\begin{array}{l}18.00- \\
72.50\end{array}$ & - & 0.0037 & 3.21 & 0.98 & - & - & - & - & $\begin{array}{c}0.949- \\
1.106\end{array}$ \\
\hline $\begin{array}{c}\text { Kahraman et al. } \\
(2014)\end{array}$ & 이 & $\begin{array}{r}\mathrm{Tl} \\
\mathrm{cm} \\
\end{array}$ & $40.2-70.3$ & - & 0.0659 & 2.481 & - & - & - & - & - & - \\
\hline Present Study & $\begin{array}{c}0 \\
+ \\
\hat{0} \\
0 \hat{0} \\
+\end{array}$ & $\begin{array}{l}\mathrm{FL} \\
\mathrm{mm}\end{array}$ & $29.23-63.50$ & $1-7$ & $\begin{array}{l}0.00009 \\
0.00007 \\
0.00010 \\
\end{array}$ & $\begin{array}{l}2.59 \\
2.64 \\
2.58 \\
\end{array}$ & $\begin{array}{l}0.92 \\
0.97 \\
0.94 \\
\end{array}$ & $\begin{array}{l}130.30 \\
122.70 \\
126.50 \\
\end{array}$ & $\begin{array}{l}18889 \\
14881 \\
16688 \\
\end{array}$ & $\begin{array}{l}0.039 \\
0.043 \\
0.044 \\
\end{array}$ & $\begin{array}{l}0.77 \\
0.69 \\
0.65 \\
\end{array}$ & $\begin{array}{l}0.8408 \\
0.8113 \\
0.8359 \\
\end{array}$ \\
\hline
\end{tabular}

The length of a pike with known weight and the weight of a pike with known length were calculated with the logarithmic length-weight relationship using the regression coefficient of length and weight $\left(\mathrm{W}=\mathrm{a} \mathrm{L}{ }^{\mathrm{b}}\right)$ (Table 2 and Figure 2).

Growth equations for the length of a pike at any age were calculated with the Von Bertalanffy growth equation using the age-length relationship growth data according to sex and length (Table 3). The proportional growth in both sexes and the age-length relationship curves are shown in Figure 3 - 4.

Table 2. Length-weight relationship parameters, equations and correlation coefficients

\begin{tabular}{llc}
\hline Sex & Length-weight relationship parameters & Correlation coefficients (R) \\
\hline \multirow{2}{*}{ Female } & $\mathrm{W}=0.00009657 \times \mathrm{L}^{2.5926}$ & 0.92 \\
& $\log \mathrm{W}=-4.0152+2.5926 \mathrm{Log} \mathrm{L}$ & 0.97 \\
Male & $\mathrm{W}=0.00007 \times \mathrm{LL}^{2.6389}$ & \\
Female + & $\log \mathrm{W}=-4.1549+2.6389 \log \mathrm{L}$ & 0.94 \\
Male & $\mathrm{W}=0.00010328 \times \mathrm{L}^{2.5773}$ & \\
\hline
\end{tabular}

Table 3. von Bertalanffy growth parameters and equations

\begin{tabular}{lcccc}
\hline & \multicolumn{4}{c}{ Growth parameters } \\
\cline { 2 - 5 } & $\mathbf{L}_{\infty}$ & $\mathbf{W}_{\infty}$ & $\mathbf{K}\left(\right.$ year $\left.^{-\mathbf{1}}\right)$ & $\mathbf{t}_{\mathbf{0}}$ \\
\hline Females & 130.30 & 18889 & 0.039 & -0.772 \\
Males & 122.70 & 14881 & 0.043 & -0.693 \\
Females + Males & 126.50 & 16688 & 0.044 & -0.654 \\
\hline
\end{tabular}




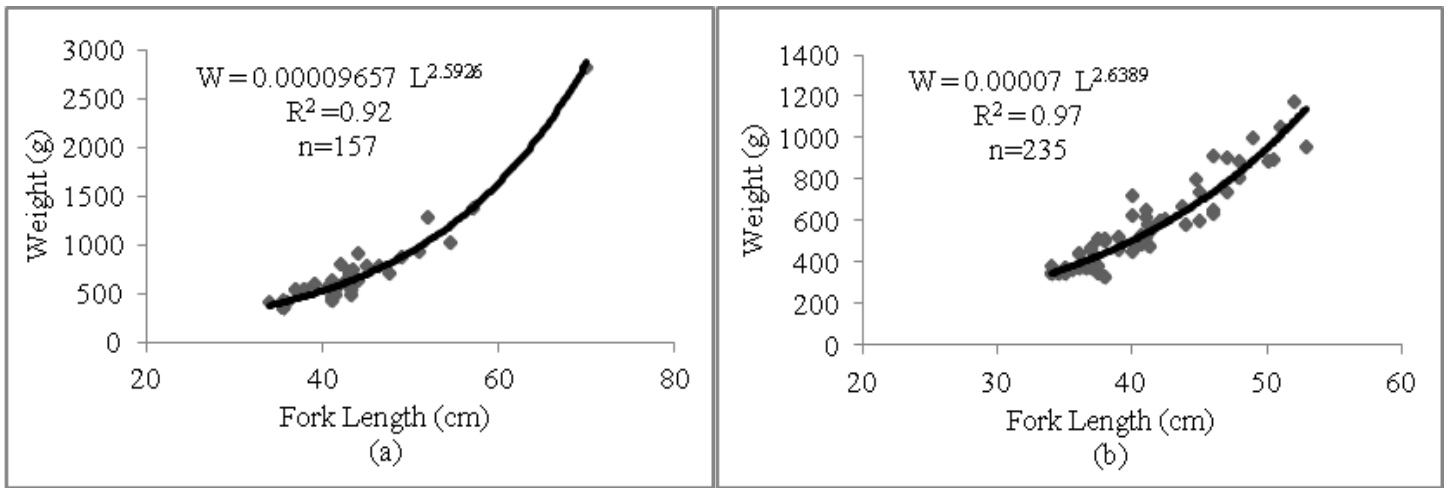

Figure 2. Length-weight relationships in females (a) and males (b)

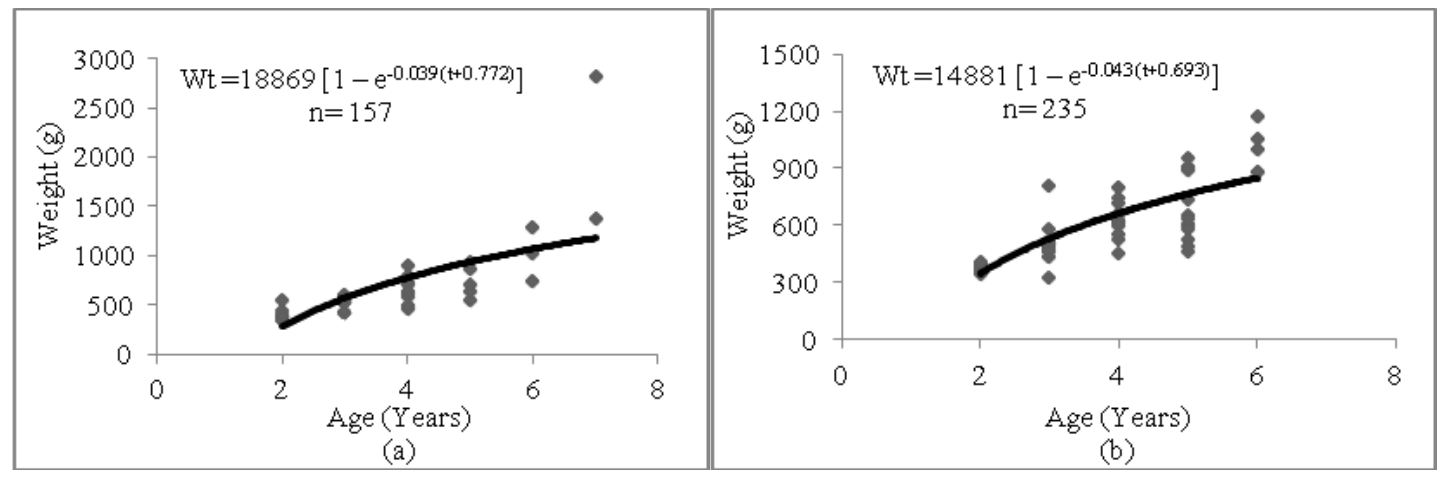

Figure 3. Age-weight relationships in females (a) and males (b)

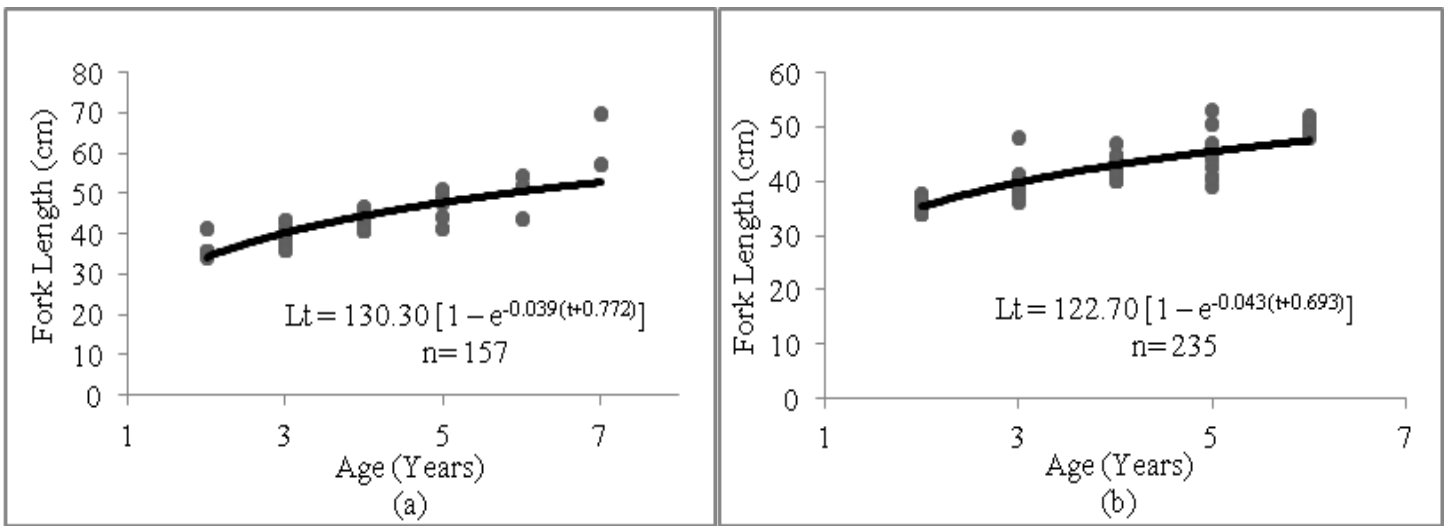

Figure 4. Age-length relationships in females (a) and males (b)

A multilayer feed-forward neural network was used for the ANN. A schematic representation of a typical ANN is shown in Figure 5 and consists of 4 interconnected layers of 'nodes' or 'neurons', including an input layer containing 1 node per independent variable (i.e. ages, length, weight and sex of pike), a hidden layer, and 
finally, an 'output layer' with 1 node (i.e. the weight or length of the fish samples). Figure 6 shows a graphical presentation of the fit between the actual and predicted values.

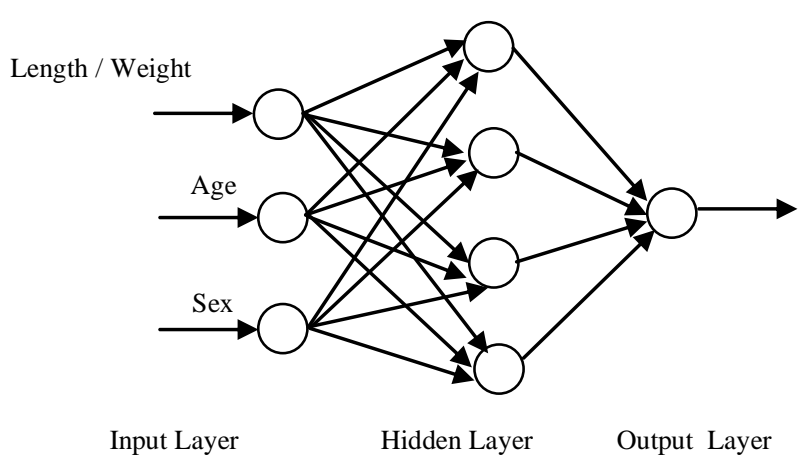

Figure 5. An ANN consisted of an input layer with 3 nodes, a hidden layer, and an output layer with 1 node to be predicted
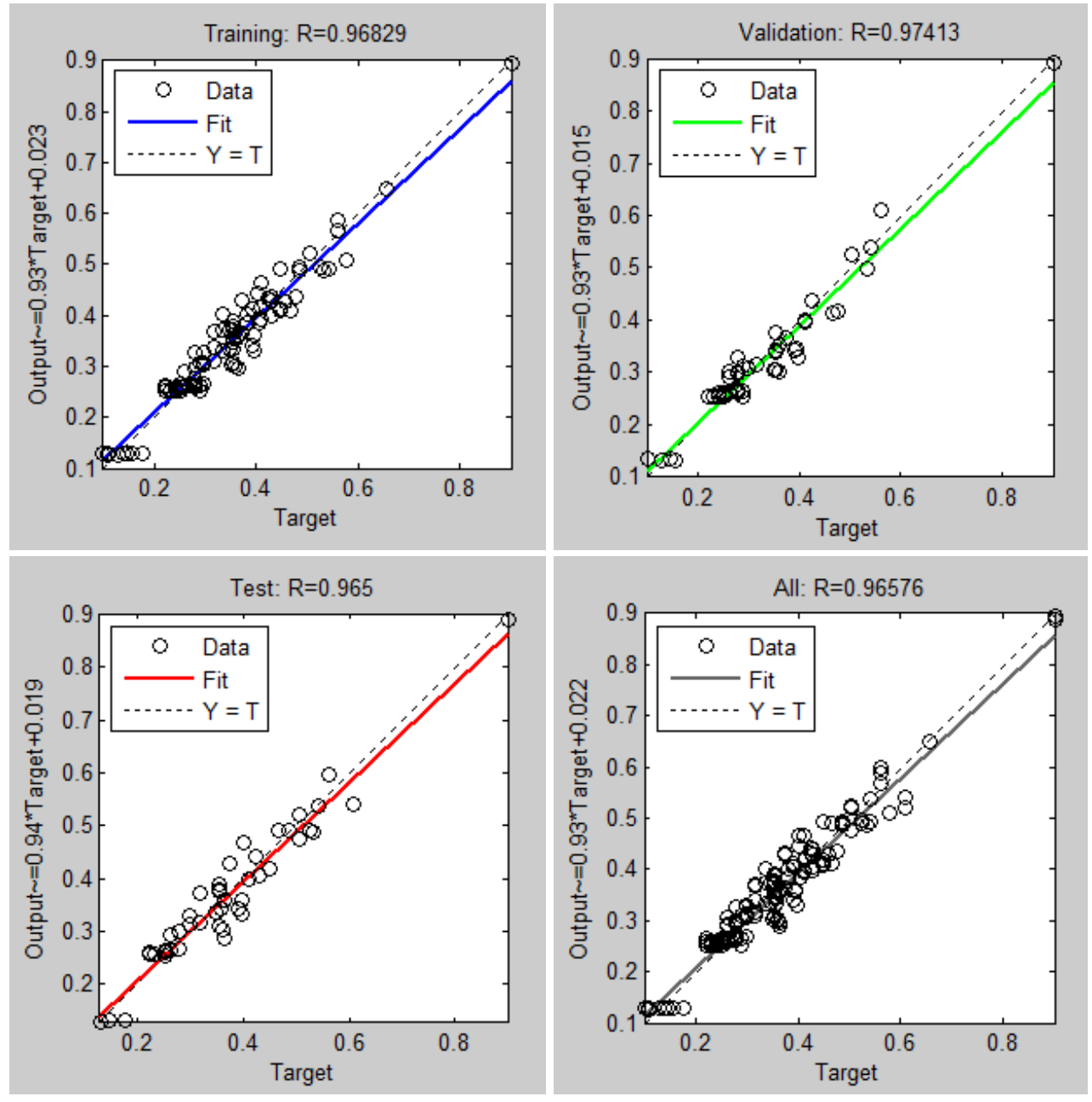

Figure 6. Relationship between the actual data and forecast values for length. 
The length-weight relationships for the Esox lucius living in Mogan Lake were $\mathrm{W}=0.00009657 \times \mathrm{L}^{2.5926}$ for females, $\mathrm{W}=0.00007 \times \mathrm{L}^{2.6389}$ for males and $\mathrm{W}=0.00010328 \times \mathrm{L}^{2.5773}$ for females+males. The $\mathrm{b}$ value for the female-male group was 2.5773. The von Bertalanffy growth equations were $L_{t}=130.30\left[1-\mathrm{e}^{-0.039{ }_{(t+0.772)}}\right]$ for females, $L_{t}=122.70\left[1-\mathrm{e}^{-0.043(t+0.693)}\right]$ for males and $L_{t}=126,50\left[1-\mathrm{e}^{-0,044(t+0,654)}\right]$ for all pike.

The condition factor (CF) of Esox lucius varied from 0.6014 to 1.1250 in males, from 0.6152 to 1.0798 in females and from 0.06014 to 1.1250 in all pike. The CF in both sexes was 0.8359 (Table 1).

\section{Discussion}

There were $36.43 \%$ females, $54.52 \%$ males and $9.05 \%$ immature fish. The ages of the pike caught from Mogan Lake ranged between I to VII years. According to Nikolskii (1980), the age distribution is affected by various ecological factors and the prime factor is the availability of food. Factors such as the mortality rate and hunting pressure also play an important role. The age distribution in Mogan Lake is similar to that found by Tanyolaç and Karabatak (1974) in Mogan Lake.

The male:female ratio was 1.49:1 for the general population. This ratio was 1.22:1 in Kesikköprü Dam Lake (Altındağ et al., 1999), 1.10:1 in Apolyont (Uluabat) Lake (Erdem et al., 2007), 1.76:1 in Trasimeno Lake (Lorenzoni et al., 2002) and 1.68:1 in Işıklı Lake (Uysal et al., 2008). The climatic conditions during the study likely affected the sexual maturity, breeding, breeding time, egg development and egg hatching (Hellawell, 1971).

Although Altındağ et al. (1999), Erdem et al. (2007), and Uysal et al. (2008) found that most of the samples were in the II-year age group, Çubuk et al. (2005) found that most of the samples were in the I-year age group in their study site.

Uysal et al. (2008) found that females were longer than males in the I, II and III year ages groups, whereas females were heavier than males in the I, II, III and V-year age groups. Erdem et al. (2007) found that females were longer than males in the I, II, IV and V-year age groups, whereas males were longer than females in the III-year age group. It was found that females were heavier than males in the I, II, III and IV-year age groups (Erdem et al., 2007). Çubuk et al. (2005) and Küçük and Güçlü (2004) found that females were longer than males in all age groups.

The length-weight relationships for the Esox lucius living in Mogan Lake were W= $0.00009657 \times \mathrm{L}^{2.5926}$ for females, $\mathrm{W}=0.00007 \times \mathrm{L}^{2.6389}$ for males and $\mathrm{W}=0.00010328 \times$ $\mathrm{L}^{2.5773}$ for females+males. The $\mathrm{b}$ value for the female-male group was 2.5773 . The $\mathrm{b}$ values determined by different researchers were generally larger than the values determined in this study (Table 1). Kahraman et al. (2014) reported similar b values (2.481).

The slope (b) value of the length-weight relationship in both sexes was 2.58 . The b value is often 3.0 and generally between 2.5 and 3.5. As the fish grows, the changes in weight are relatively greater than the changes in length due to approximately cubic relationships between fish length and weight. The $b$ values in fish are species specific and vary with sex, age, seasons, physiological conditions, growth increment and nutritional status of the fish (Ricker, 1975; Baganel and Tesch, 1978).

Variations in fish growth in terms of length and weight can be explained as an adaptive response to different ecological conditions (Nikolsky, 1963). The von Bertalanffy growth equations were $\mathrm{L}_{\mathrm{t}}=130.30\left[1-\mathrm{e}^{-0.039(\mathrm{t}+0.772)}\right]$ for females, $\mathrm{L}_{\mathrm{t}}=$ 
$122.70\left[1-\mathrm{e}^{-0.043(\mathrm{t}+0.693)}\right]$ for males and $\mathrm{L}_{\mathrm{t}}=126,50\left[1-\mathrm{e}^{-0,044(\mathrm{t}+0,654)}\right]$ for all pike. The "K" value, known as the Brody coefficient, was 0.0772 in females and 0.043 in males. Munro and Pauly (1983) state that the " $\mathrm{K}$ " value is an indicator of the growth performance of the species. $\mathrm{L}_{\infty}$ was similar to that of Çubuk et al. (2005) and Ziliukiene and Ziliukas (2010), but was different from other studies (Karabatak, 1993; Treer et al., 1998; Altındağ et al., 1999; Lorenzoni et al., 2002; Küçük and Güçlü, 2004, Uysal et al., 2008).

The condition factor (CF) of Esox lucius varied from 0.6014 to 1.1250 in males, from 0.6152 to 1.0798 in females and from 0.06014 to 1.1250 in all pike. The CF in both sexes was 0.8359 (Table 1). The results are consistent with several earlier reports (Karabatak, 1993; Küçük and Güçlü, 2004), although they differed from studies performed by Altındağ et al., 1999 and Erdem et al., 2007. The condition factor provides important information about the effect of feeding habits and the population density of the fish on their growth and gonad development (Weatherley, 1972).

Gutierrez-Estrade et al. (2004), Türeli Bilen et al. (2011) and Benzer (2014) performed similar studies. Traditional growth models were also used for predictions together with ANN. The values obtained for the actual, ANNs, W-L relationship and von Bertalanffy data are presented in Table 4.

Traditional methods of statistical analysis (i.e. linear regression models, both single and multiple) may be inadequate for quantification (Maravelias et al., 2003). ANNs offer a promising alternative to traditional statistical approaches for predictive modelling when non-linear patterns exist (Joy and Death, 2004). Recently, ANNs have been used in biology and various disciplines of aqua-cultic ecology more than in physical or chemical sciences. Most of these studies demonstrated that ANNs perform better than classical linear regression and generalized additive models (Brosse et al., 1999).

Table 4. Predicted and calculated values for ANNs, the length-weight relationship and von Bertalanffy

\begin{tabular}{|c|c|c|c|c|c|c|c|c|c|c|c|c|c|c|c|}
\hline \multirow{3}{*}{$\begin{array}{l}\overline{\bar{v}} \\
\stackrel{\bar{v}}{0} \\
0\end{array}$} & \multirow{3}{*}{ \& } & \multirow{2}{*}{\multicolumn{2}{|c|}{$\begin{array}{c}\text { ACTUAL } \\
\text { DATA }\end{array}$}} & \multicolumn{4}{|c|}{ ANNs } & \multicolumn{4}{|c|}{ W - L Relationship } & \multicolumn{4}{|c|}{ von Bertalanffy } \\
\hline & & & & \multicolumn{2}{|c|}{ FORECAST } & \multicolumn{2}{|c|}{ MAPE (\%) } & \multicolumn{2}{|c|}{ CALCULATED } & \multicolumn{2}{|c|}{ MAPE (\%) } & \multicolumn{2}{|c|}{ CALCULATED } & \multicolumn{2}{|c|}{ MAPE (\%) } \\
\hline & & $\mathrm{L}$ & W & $\mathrm{L}$ & $\mathrm{W}$ & $\mathrm{L}$ & W & $\mathrm{L}$ & W & $\mathrm{L}$ & W & $\mathrm{L}$ & W & $\mathrm{L}$ & W \\
\hline $\mathrm{A}$ & 1 & 29.23 & 240.00 & 29.03 & 245.56 & 0.692 & 2.264 & 29.51 & 234.00 & 0.954 & 2.500 & 35.72 & 291.66 & 22.186 & 21.525 \\
\hline $\mathrm{F}$ & & 35.91 & 395.81 & 35.96 & 384.52 & 0.153 & 2.936 & 35.52 & 406.83 & 1.072 & 2.784 & 41.11 & 528.62 & 14.50 & 33.55 \\
\hline M & 2 & 35.87 & 369.87 & 36.25 & 370.36 & 1.054 & 0.132 & 35.28 & 386.21 & 1.639 & 4.418 & 39.12 & 430.33 & 9.08 & 16.35 \\
\hline A & & 35.88 & 378.36 & 36.16 & 380.61 & 0.772 & 0.591 & 35.21 & 396.98 & 1.870 & 4.921 & 39.62 & 456.66 & 10.43 & 20.69 \\
\hline $\mathrm{F}$ & & 39.54 & 531.00 & 39.38 & 537.92 & 0.416 & 1.286 & 39.79 & 522.53 & 0.622 & 1.595 & 44.52 & 676.82 & 12.59 & 27.46 \\
\hline M & 3 & 39.31 & 508.91 & 39.92 & 510.94 & 1.533 & 0.397 & 39.82 & 491.79 & 1.303 & 3.364 & 42.64 & 624.61 & 8.48 & 22.73 \\
\hline A & & 39.41 & 518.38 & 39.67 & 523.75 & 0.658 & 1.025 & 39.79 & 505.57 & 0.967 & 2.471 & 43.36 & 672.22 & 10.03 & 29.68 \\
\hline $\mathrm{F}$ & & 42.81 & 667.38 & 43.51 & 677.09 & 1.613 & 1.434 & 43.45 & 641.81 & 1.500 & 3.831 & 47.80 & 843.72 & 11.67 & 26.42 \\
\hline M & 4 & 41.98 & 632.10 & 41.94 & 584.19 & 0.100 & 8.201 & 43.23 & 585.05 & 2.973 & 7.443 & 46.01 & 784.69 & 9.60 & 24.14 \\
\hline A & & 42.41 & 650.51 & 42.80 & 634.86 & 0.904 & 2.465 & 43.45 & 610.93 & 2.445 & 6.084 & 46.94 & 852.76 & 10.68 & 31.09 \\
\hline $\mathrm{F}$ & & 46.60 & 740.11 & 45.01 & 740.23 & 3.533 & 0.016 & 45.22 & 799.78 & 2.961 & 8.062 & 50.96 & 1028.62 & 9.35 & 38.98 \\
\hline M & 5 & 47.12 & 688.47 & 44.88 & 710.09 & 4.980 & 3.045 & 44.65 & 703.37 & 5.232 & 2.164 & 49.24 & 961.68 & 4.51 & 39.68 \\
\hline A & & 47.96 & 702.82 & 44.95 & 719.61 & 6.687 & 2.333 & 44.78 & 730.37 & 6.623 & 3.920 & 50.37 & 1053.34 & 5.03 & 49.87 \\
\hline $\mathrm{F}$ & & 50.51 & 1019.00 & 52.42 & 1073.45 & 3.644 & 5.072 & 51.16 & 959.98 & 1.287 & 5.792 & 53.99 & 1344.00 & 6.90 & 31.89 \\
\hline M & 6 & 49.72 & 997.80 & 50.55 & 1009.60 & 1.642 & 1.169 & 51.39 & 928.90 & 3.359 & 6.905 & 52.33 & 1154.45 & 5.25 & 15.70 \\
\hline A & & 50.31 & 1005.75 & 51.30 & 1035.14 & 1.924 & 2.839 & 51.46 & 934.29 & 2.280 & 7.105 & 53.64 & 1272.63 & 6.62 & 26.54 \\
\hline $\mathrm{F}$ & & 63.50 & 2100.50 & 62.62 & 2077.27 & 1.405 & 1.118 & 67.63 & 1783.97 & 6.504 & 15.069 & 56.91 & 1573.94 & 10.37 & 25.07 \\
\hline A & 7 & 63.50 & 2100.50 & 62.62 & 2077.27 & 1.405 & 1.118 & 68.48 & 1728.78 & 7.843 & 17.697 & 56.78 & 1509.13 & 10.58 & 28.15 \\
\hline \multicolumn{6}{|c|}{ Average MAPE } & 1.840 & 2.080 & & & 2.850 & 5.900 & & & 2.36 & 9.24 \\
\hline
\end{tabular}

F: Female, M: Male, A: Female+Male, AI: All Individuals

In this study, the application of the ANN was compared to a conventional linear approach. As a result, ANNs can be an alternative to the von Bertalanffy growth 
models. By contrast, the estimated growth parameters are model dependent; therefore, model selection uncertainty may be quite high in certain data sets. Ignoring model selection uncertainty may cause a substantial overestimation of the precision and estimation of the confidence intervals of the parameters below the nominal level. This uncertainty has serious implications, particularly when comparing the growth parameters of different fish populations. The set of candidate models should include at least the von Bertalanffy model, one or more sigmoid growth curves, and one or more non-asymptotic models (Katsanevakis and Maravelias, 2008). The von Bertalanffy model can be used to predict the features of a prospective older population from their sample caught when younger. The von Bertalanffy model provides better results with advancing age (Narinc et al., 2010).

In conclusion, the current study demonstrates that ANNs can be an alternative to von Bertalanffy growth models. In addition, it is recommended that the necessary steps should be taken as soon as possible to protect the Esox lucius population in the lake after investigating its stock situation and breeding and feeding behaviours.

Acknowledgments. We would like to thank all of the referees, who added value to our paper with their thorough reviews and recommendations.

\section{REFERENCES}

[1] Aksun, F.Y. (1978): The Growth and Growth Rates of Pike (Esox lucius L., 1758) in Karamık Lake. - Turkish Journal of Zoology 11(2): 76-86.

[2] Altındağ, A., Yiğit, S., Ahiska, S., Özkurt, Ş. (1999): The Growth Features of Pike (Esox lucius L., 1758) in Dam Lake Kesikköprü. - Tr.J.of Zoology 23:901-910.

[3] Anonymous (1989): Turkey's Wetlands. Environmental Problems Foundation of Turkey. Lagler, K.F., 1966: Freshwater fishery biology. - W.M.C. Brown Company, Dubuque, IA. p.421.

[4] Baganel, T.B., Tesch, F.W. (1978): Age and Growth. - In: Baganel, T.B. (Ed) Method for assessment of fish production in fresh waters. - London Blackwell Scientific Publications. p.136.

[5] Benzer, R. (2014): Population Dynamics Forecasting Using Artificial Neural Networks. Fresenius Environmental Bulletin 12(1): 14-26.

[6] Brosse, S., Guegan, J., Tourenq, J., Lek, S. (1999): The Use of Artificial Neural Networks to Assess Fish Abundance and spatial occupancy in the littoral zone of a mesotrophic lake. - Ecological Modelling 120(2-3): 299-311.

[7] Casselman, J.M., Lewis, C.A. (1996): Habitat requirements of northern pike (Esox lucius). - Can. J. Fish. Aquat. Sci. 53:161-174.

[8] Christiansen, N.H., Voie, E.T., Winther, O., Høgsberg, J. (2014): Comparison of Neural Network Error Measures for Simulation of Slender Marine Structures. - Journal of Applied Mathematics pp.1-11.

[9] Çubuk, H., Balık, İ., Uysal, R., Özkök, R. (2005): Some Biological Characteristics and the Stock Size of the Pike (Esox lucius L., 1758) Population in Lake Karamık (Afyon, Turkey). - Turk J Vet Anim Sci. 29:1025-1031.

[10] Desilets, L., Golden, B., Wang, Q., Kumar, R. (1992): Predicting salinity in the Chesapeake Bay using backpropagation. - Computers \& Operations Research 19: 227285.

[11] Erdem, Ü., Atasoy, E., Emre, Y., Çeliktaş, S. (2007): Some Biological Characteristics of Pike (Esox Lucius Linnaeus, 1758) In Lake Apolyont (Uluabat/Bursa-Turkey). - Turkish Journal Of Aquatic Life. 3-5(5.8): 413-418. 
[12] Gaygusuz, Ö., Gürsoy, Ç., Özuluğ, M., Tarkan, A.S., Acıpınar, H., Bilge, G., Filiz, H. (2006): Conversions of Total, Fork and Standard Length Measurements Based on 42 Marine and Freshwater Fish Species (from Turkish Waters). - Turkish Journal of Fisheries and Aquatic Sciences 6: 79-84.

[13] Gutierrez-Estrade, J.C., Pedro-Sanz, E., Lopez-Luque, R., Pulido-Calvo, I. (2004): Comparison between tradional methods and artificial neural networks for ammonia concerntration forecasting in an eel (Anguilla Anguilla L) intensive rearing system. Aquacultural Enginnering. 31: 183-203.

[14] Hamzacebi, Ç., Kutay, F. (2004): Electric Consumption Forecasting of Turkey Using Artificial Neural Networks up to Year 2010. - Journal of the Faculty of Engineering and Architecture of Gazi University 19: 227-233.

[15] Haykin, S. (1999): Neural Networks: A Comprehensive Foundation. - Perenctice Hall, New Jersey.

[16] Hellawell, J.M. (1971): The autecology of the chub Squalis cephalus (L.) of at the River Luggan the aton liynfi. - Freshwater Biology 1: 29-60.

[17] Hill, T., O'connor, M., Remus, W. (1996): Neural Networks Models for Time Series Forecasts. - Management Sciences 42:1082-1092.

[18] Hopgood, A.A. (2000): Intelligent systems for engineers and scientists, Florida: CRC Press.

[19] Joy, K.M., Death, R.G. (2004): Predictive modelling and spatial mapping of freshwater fish and decapod assemblages using GIS and neural Networks. - Freswater Biolgogy 49 (8): 1306-1052.

[20] Kahraman, A.E., Göktürk, D., Aydin, E. (2014): Length-Weight Relationships of Five Fish Species from the Sakarya River, Turkey. - Annual Research \& Review in Biology 4(15): 2476-2483.

[21] Karabatak, M. (1993): Growth and Mortality Rate, Age-Length Composition of Pike (Esox lucius L.,1758) in Lake Akşehir. - Tr.J.of Biology 17: 211-226.

[22] Karabatak, M. (1993): Growth and Mortality Rate, Age-Length Composition of Pike (Esox lucius L., 1758) in Lake Akşehir. - Doğa Tr.J.of Biology 17: 211-226.

[23] Katsanevakis, S., Maravelias, C.D. (2008): Modelling fish growth: multi-model inference as a better alternative to a priori using von Bertalanffy equation. - Fish and Fisheries 9: 178-187.

[24] Küçük, F., Güçlü, S.S. (2004): Growth and food of pike (Esox lucius L., 1758) population in Lake Çapalı (Afyon-Isparta). - Journal of Eğirdir Fisheries Faculty 2(12): 32-38.

[25] Lorenzoni, M., Corboli, M., Dörr, A.J.M., Mearelli, M., Giovinazzo, G. (2002): The Growth of pike (Esox lucius Linnaeus, 1758) in Lake Trasimeno (Umbria, Italy). Fisheries Research 59: 239-246.

[26] Maravelias, C.D., Haralabous, J., Papaconstantinou, C. (2003): Predicting demersal fish species distri butions in the Mediterranean Sea using artificial neural networks. - Marine Ecology. Progress Series 255: 249-258.

[27] Matlab (2006): The MathWorks, Inc. Matlab Help. MATLAB.

[28] Moslemi-Aqdam, M., Namin, J.I., Sattari, M., Abdolmalaki, S.H., Bani, A. (2014): Length- length, length -weight relationship and relative condition factor of pike, Esox lucius Linnaeus, 1758, in Anzali Wetland (Southwest of the Caspian Sea). - Caspian J. Env. Sci. 12(1): 109-117.

[29] Munro, J.L., Pauly, D. (1983): A simple method for comparing the growth of fish and invertebrates. - Fishbyte 1(1): 5-6.

[30] Narinc, D., Karaman, E., Firat, M.Z., Aksoy, T. (2010): Comparison of non-linear growth models to describe the growth in Japanese Quail. - Journal of Animal and Veterinary Advances 9:1961-1966.

[31] Nikolskii, G.W. (1980): Theory of Fish Population Dynamics. - Otto Koetz Science Publishers. Koenigatein. 
[32] Nikolsky, G.V. (1963): The Ecology of Fishes. - Academic Press London, London, p. 352.

[33] Ricker, W.E. (1973): Linear regressions in fishery research. - J. of Fisheries Research Board of Canada 30: 409-434.

[34] Ricker, W.E. (1975): Computation and interpretation of biological statistics of fish population. - Bull. Fih. Res. Bd. Can. 191: 382.

[35] Rumelhart, D.E., Hinton, G.E. Williams, R.J. (1986): Learning internal representations by error propagation. - In: Parallel Distributed Processing. Explorations in the Microstructure of Cognition, MIT Press 1: 318-362.

[36] Sparre, P., Venema, S.C. (1992): Intoduction to tropical fish stock assessment. Part 1. Manual. FAO Fisheries Technical Paper no 306. (Rev. 1). FAO, Rome, p. 376.

[37] Sun, L., Xiao, H., Li, S, Yang, D. (2009): Forecasting fish stock recruitment and planning optimal harvesting strategies by using neural network. - Journal of Computers 4(11): 1075-1082.

[38] Suryanarayana, I., Braibanti, A., Rao, R.S., Ramamc, V.A., Sudarsan, D., Rao, G.N. (2008): Neural networks in fisheries research. - Fisheries Research 92: 115-139.

[39] Tanyolac, J., Karabatak, M. (1974): Biology and Hydrology Properties of Population in Mogan Lake.- TUBITAK Press 225: 21-28.

[40] Treer, T., Habekovic, R., Safner, R., Anicic, A, Kolak, A. (1998): Growth of Pike (Esox lucius L.) in Croatian Reservoir Kruscica. - Ribastvo 56(3): 85-90.

[41] Tureli Bilen, C., Kokcu, P., Ibrikci, T. (2011): Application of Artificial Neural Networks (ANNs) for Weight Predictions of Blue Crabs (Callinectes sapidus Rathbun, 1896) Using Predictor Variables. - Mediterranean Marine Science 12(2): 439-446.

[42] Uysal, R., Yağc1, M.A., Yeğen, V., Alp, A., Yağc1, A. (2008): The growth features of Pike (Esox lucius L., 1758) Population in Lake Işıklı (Çivril-Denizli). - E.U. Journal of Fisheries \& Aquatic Sciences 25(4): 259-265.

[43] Weatherley, A. H. (1972): Growth and ecology of fish populations. - Academic Press, London, p. 293.

[44] Yağc1, A.M., Alp, A., Uysal, R., Yeğen, V., Yağc1, A. (2009): Reproduction Properties of Pike (Esox lucius L.,1758) Population in the Işıklı Dam Lake (Çivril-Denizli/Turkey). Journal of Fisheries Sciences 3(3): 220-230.

[45] Ziliukiene, V., Ziliukas, V. (2010): Growth of pike Esox lucius L. in Lake Rubikiai (Lithuania). - J. Appl. Ichthyol. 26: 898-903. 